\title{
The Gln27Glu Polymorphism in $\beta 2$-Adrenergic receptor gene is linked to hypertriglyceridemia, hyperinsulinemia and hyperleptinemia in Saudis
}

\author{
Maha H Daghestani ${ }^{1 *}$, Arjumand Warsy ${ }^{2}$, Mazin H Daghestani ${ }^{3}$, Ali N Al-odaib ${ }^{4}$, Abdelmoneim Eldali ${ }^{5}$, \\ Nadia A Al-Eisa', Sabah Al-zhrani²
}

\begin{abstract}
Background: $\beta 2$-adrenoceptor ( $\beta 2 \mathrm{AR}$ ) gene polymorphism glutamine 27 glutamic acid (Gln27Glu) and Arg16Gly were reported to have an association with obesity and obesity related disorders in some population. We evaluated Gln27Glu polymorphism in the $\beta 2 A R$ gene in obese Saudi populations to investigate the association of $\beta 2 A R$ gene with obesity and other related metabolic parameters.

Design: We studied possible association of Gln27Glu in $\beta 2 A R$ gene with body mass index (BMI), anthropometric measurements and other metabolic parameters. The $\beta 2 A R$ gene polymorphism (Gln27Glu) was identified by sequencing PCR products representing locus of interest. Based on BMl, the subjects were divided into three groups, normal weight, overweight and obese. The genotype and allele frequency were calculated separately for each group.

Results: The allelic frequency of Glu27 did not differ amongst the three groups, though the Glu27 homozygote $(\mathrm{Glu} / \mathrm{Glu})$ were more in obese subjects and had higher concentration of triglyceride, leptin and insulin compared to in the $\mathrm{G} \ln 27$ heterozygotes and $\mathrm{G} \ln / \mathrm{G} \ln$ homozygotes.

Conclusions: In this study we were able to provide evidence on the influence of GIn27Glu genetic variant of $\beta 2 A R$ gene on lipid phenotypes, insulin and leptin levels in the Saudi populations.
\end{abstract}

\section{Background}

Obesity is serious health problem among men and women. It is a multifactorial phenotype determined by genetic and non genetic factors including environmental and behavioral characteristics [1]. Extensive studies have been conducted in different populations to identify the loci contributing to obesity development. In the process, a complex picture has emerged where inter-population differences in the susceptibility genes are observed. It has been observed that catecholamines act through both $\beta$ - and $\alpha$ adrenergic receptor which mediate through different receptor pathways [2]. Genes involved in the regulation of catecholamine function may be of particular importance for human obesity, since catecholamine

\footnotetext{
* Correspondence: mahadaghestani@yahoo.com

'Department of Zoology, Center for Scientific and Medical Female Colleges, King Saud University, P.O. Box 22455, Riyadh, Saudi Arabia

Full list of author information is available at the end of the article
}

via $\beta 2-3$ adrenergic receptors or adrenoceptors, regulate body fat accumulation and play a central role in the regulation of energy expenditure [3]. This regulation is in part affected by the stimulation of lipid mobilization through lipolysis in fat cells, which has been associated with obesity $[4,5] . \beta 2 \mathrm{AR}$ are expressed in many cell types throughout the body and play a crucial role in the regulation of the cardiac, pulmonary, vascular, endocrine and central nervous system. Several functional polymorphisms occur within the coding region of this gene. The Gln27Glu polymorphism in the $\beta 2 \mathrm{AR}$ gene has been considered important factor contributing to obesity [6]. Among these, a common mutation results is the substitution of an amino acid in the extracellular domain of the receptor, Gln27Glu [7]. This appears to modify the extracellular part of the $\beta 2 \mathrm{AR}$ with possible functional modification. 
Recent studies on some ethnic groups have shown that this polymorphism is associated with obesity, insulin resistance and dyslipidemia [8-10]. However, reports from other populations contradict these results [11-13]. In some studies, gender differences in relation to the polymorphism are reported [14-16]

In an attempt to elucidate the influence of the $\beta 2 \mathrm{AR}$ polymorphisms on obesity development, we investigated the association of Gln27Glu gene in obesity and its influence on other metabolic profiles.

\section{Materials and methods Subjects}

This study included 329 unrelated Saudi men ( $\mathrm{n}=109$, $33.1 \%)$ and women $(\mathrm{n}=220,66.9 \%)$ aged 18 to 36 years, randomly chosen from a nationwide population. All the study subjects gave their written consent to participate in the study after being informed of its nature. The study was approved by local ethical committee of the university. They agreed to have venous blood drawn after an overnight fasting. For laboratory studies, $20 \mathrm{ml}$ of blood was obtained in the morning following an overnight (12 hour) fast. Blood samples were collected in EDTA-coated tubes and immediately centrifuged at room temperature. The buffy coat and the plasma were stored at $-20^{\circ} \mathrm{C}$ until required for analysis.

\section{Anthropometric Measurements}

For each individual, anthropometric measurements were made using standardized techniques. These included measurement of height, weight, waist and hip circumference and these were used to calculate BMI $\left(\mathrm{kg} / \mathrm{m}^{2}\right)$, and waist-to-hip ratio (WHR).

\section{Biochemical Parameters}

Plasma glucose level was estimated from the fresh samples by glucose-oxidase method adapted to an autoanalyzer (Hitachi 704, Boehringer Mannheim, GmBH, Germany). Frozen plasma samples were thawed at room temperature and used for the analysis of the other biochemical parameters. The estimation of total cholesterol, triglycerides, high density lipoprotein (HDL)-cholesterol and low-density lipoprotein (LDL)-cholesterol were carried out by enzymatic methods using commercial kits (Boehringer Mannheim). Plasma insulin and leptin concentrations were determined by radioimmunoassay (RIA; Human Insulin Specific RIA kit and Human Leptin RIA Kit, respectively, Linco Research, St Louis, MO). All analyses were conducted in duplicates. Quality control was maintained within and between the batches.

\section{Genotyping of $\beta 2 A R$ Polymorphism}

Genomic DNA was extracted from peripheral blood leucocytes using commercially available Gentra Systems Kit
(Minneapolis, MN, cat \# D5500). The concentration and purity of the DNA were estimated prior to analysis and DNA was used for the following studies:

The DNA segment representing codon 27 of the $\beta 2 \mathrm{AR}$ gene was amplified by polymerase chain reaction (PCR) using forward (5'-AAGCTGAGTGTGCAGGACGA-3') and reverse primers (5'-AGACGCTCGAACTTGGCAAT-3'). The PCR conditions consisted of an initial denaturation step at $95^{\circ} \mathrm{C}$ for 15 minutes, followed by 34 cycles of denaturation at $95^{\circ} \mathrm{C}$ for $1 \mathrm{~min}$ ute, annealing at $64^{\circ} \mathrm{C}$ for 1 minute, and extension at $72^{\circ} \mathrm{C}$ for 1 minute, with a final extension of 10 minutes at $72^{\circ} \mathrm{C}$. A PCR product of $353 \mathrm{bp}$ was obtained. Nucleotide sequencing was carried out using the ABI Big Dye Terminator protocol on ABI 3100 Avant Genetic Analyzer.

\section{Statistical analysis}

The subjects were grouped as normal weight (BMI $<25 \mathrm{Kg} / \mathrm{m}^{2}$ ), overweight (BMI $25-29.9 \mathrm{Kg} / \mathrm{m}^{2}$ ) and

Table 1 Mean comparisons of anthropometric characteristics of the overweight and obese groups with the normal control group

\begin{tabular}{|c|c|c|c|c|}
\hline VARIABLES & $\begin{array}{c}\text { Control } \\
\text { Lean } \\
(n=115) \\
\text { mean } \pm \text { SE }\end{array}$ & $\begin{array}{c}\text { Overweight } \\
(n=68) \text { mean } \pm \\
\text { SE }\end{array}$ & $\begin{array}{c}\text { Obese } \\
(n=146) \\
\text { mean } \pm S E\end{array}$ & $\begin{array}{c}P \\
\text { value }\end{array}$ \\
\hline \multicolumn{5}{|l|}{ Age (yr) } \\
\hline$M$ & $25.9 \pm 0.7$ & $27.3 \pm 0.67$ & $26.7 \pm 0.73$ & \multirow[t]{3}{*}{0.056} \\
\hline $\mathrm{F}$ & $24.5 \pm 0.5$ & $24.4 \pm 0.7$ & $26.7 \pm 0.54$ & \\
\hline $\mathrm{T}$ & $24.90 \pm 0.44$ & $25.56 \pm 0.54$ & $26.70 \pm 0.43$ & \\
\hline \multicolumn{5}{|l|}{$\begin{array}{l}\mathrm{BMI}(\mathrm{kg} / \\
\left.\mathrm{m}^{2}\right)\end{array}$} \\
\hline$M$ & $21.27 \pm 0.34$ & $26.4 \pm 0.27$ & $32.9 \pm 0.8$ & \multirow[t]{3}{*}{0.0001} \\
\hline $\mathrm{F}$ & $21.4 \pm 0.20$ & $27.3 \pm 0.2$ & $35.8 \pm 0.6$ & \\
\hline $\mathrm{T}$ & $\begin{array}{c}21.33 \pm \\
0.189\end{array}$ & $26.93 \pm 0.170$ & $34.89 \pm 0.50$ & \\
\hline \multicolumn{5}{|l|}{ Waist (cm) } \\
\hline M & $74.2 \pm 1.53$ & $86.1 \pm 1.4$ & $110.5 \pm 2.2$ & \multirow[t]{3}{*}{0.0001} \\
\hline $\mathrm{F}$ & $67.3 \pm 0.9$ & $84.4 \pm 1.23$ & $100.6 \pm 1.38$ & \\
\hline $\mathrm{T}$ & $70.82 \pm 0.79$ & $85.13 \pm 0.93$ & $103.72 \pm 1.23$ & \\
\hline \multicolumn{5}{|l|}{ Hip (cm) } \\
\hline$M$ & $97.6 \pm 1.2$ & $100.8 \pm 1.17$ & $122.2 \pm 2.0$ & \multirow[t]{3}{*}{0.0001} \\
\hline $\mathrm{F}$ & $95.5 \pm 0.8$ & $102.2 \pm 1.1$ & $118.5 \pm 1.4$ & \\
\hline $\mathrm{T}$ & $96.13 \pm 0.68$ & $102.22 \pm 0.821$ & $\begin{array}{c}119.68 \pm \\
1.148\end{array}$ & \\
\hline \multicolumn{5}{|l|}{ W/H Ratio } \\
\hline$M$ & $0.76 \pm 0.02$ & $0.86 \pm 0.01$ & $0.90 \pm 0.01$ & \multirow[t]{3}{*}{0.0001} \\
\hline $\mathrm{F}$ & $0.72 \pm 0.01$ & $0.82 \pm 0.02$ & $0.85 \pm 0.007$ & \\
\hline $\mathrm{T}$ & $0.73 \pm 0.006$ & $0.84 \pm 0.006$ & $0.87 \pm 0.006$ & \\
\hline
\end{tabular}

NOTE: Values are mean \pm SEM. Abbreviations: $\mathrm{BMI}$, body mass index; $\mathrm{W} / \mathrm{H}$, waist hip ratio; $\mathrm{M}=$ Male; $\mathrm{F}=$ Female; $\mathrm{T}=$ Total. 
obese $\left(\mathrm{BMI}>30 \mathrm{Kg} / \mathrm{m}^{2}\right)$, based on their BMI conditions. The analysis was done using the Stat View program for Windows (version 8.0; SAS) and the SPSS (Statistical Package for Social Sciences; Version 13).

The data are presented as mean \pm SEM for the males and females separately. The comparisons of the results of the overweight and obese subjects with the results of the matched control were carried out using the independent Students T-test and ANOVA test. The distributions of the age, BMI, anthropometric measurements, lipid profile, fasting serum insulin, leptin and glucose values of the study subjects according to their $\beta 2 A R$ gene were compared by the U Mann-Whitney test. Multivariable logistic regression was used to study the effect of the $\beta 2 \mathrm{AR}$ genotype on BMI. Genotype and allele frequency of $\beta 2 A R$ alleles were calculated separately for the normal weight, overweight and obese individuals and compared using chi square analysis. Frequency distribution analysis was performed with chi square test. Relative risk was estimated by the odds ratios (ORs) and their $95 \%$ confidence intervals (CIs). A probability value $\mathrm{p} \leq 0.05$ was considered statistically significant.

\section{Results and discussion}

Based on the BMI value, there were 35, 28, 46 males and $80,40,100$ females in the normal weight, overweight and obese groups, respectively. The demographic characteristics of the male and female study subjects are presented in Table 1. All the three groups matched in their age and no significant differences were observed amongst the groups. All other demographic parameters were significantly higher in overweight and obese

Table 2 Comparison of the biochemical parameters of the overweight and obese groups with the normal control group

\begin{tabular}{|c|c|c|c|c|}
\hline VARIABLES & $\begin{array}{c}\text { Control Lean } \\
(n=115) \\
\text { mean } \pm \text { SE }\end{array}$ & $\begin{array}{c}\text { Overweight } \\
(\mathrm{n}=68) \text { mean } \pm \mathrm{SE}\end{array}$ & $\begin{array}{c}\text { Obese } \\
(n=146) \\
\text { mean } \pm \text { SE }\end{array}$ & $P$ value \\
\hline \multicolumn{5}{|l|}{ Cholesterol (mmol/L) } \\
\hline M & $3.31 \pm 0.07$ & $4.4 \pm 0.15$ & $4.1 \pm 0.11$ & 0.0001 \\
\hline $\mathrm{F}$ & $3.5 \pm 0.05$ & $4.05 \pm 0.12$ & $4.5 \pm 0.09$ & \\
\hline $\mathrm{T}$ & $3.43 \pm 0.043$ & $4.194 \pm 0.096$ & $4.4 \pm 0.074$ & \\
\hline \multicolumn{5}{|l|}{ Triglyceride $(\mathrm{mmol} / \mathrm{L})$} \\
\hline M & $0.79 \pm 0.05$ & $1.15 \pm 0.08$ & $1.43 \pm 0.07$ & 0.0001 \\
\hline $\mathrm{F}$ & $0.72 \pm 0.05$ & $1.03 \pm 0.06$ & $1.24 \pm 0.04$ & \\
\hline$T$ & $0.742 \pm 0.024$ & $1.082 \pm 0.05$ & $1.302 \pm 0.04$ & \\
\hline \multicolumn{5}{|l|}{ HDL-cholesterol (mmol/L) } \\
\hline M & $1.28 \pm 0.06$ & $1.21 \pm 0.07$ & $1.08 \pm 0.04$ & 0.0001 \\
\hline $\mathrm{F}$ & $1.34 \pm 0.04$ & $1.17 \pm 0.05$ & $1.06 \pm 0.03$ & \\
\hline $\mathrm{T}$ & $1.32 \pm 0.033$ & $1.19 \pm 0.043$ & $1.07 \pm 0.024$ & \\
\hline \multicolumn{5}{|l|}{ LDL -cholesterol (mmol/L) } \\
\hline M & $1.58 \pm 0.09$ & $2.25 \pm 0.15$ & $2.4 \pm 0.11$ & 0.0001 \\
\hline$F$ & $1.53 \pm 0.06$ & $1.94 \pm 0.11$ & $2.6 \pm 0.07$ & \\
\hline$T$ & $1.55 \pm 0.05$ & $2.07 \pm 0.89$ & $2.56 \pm 0.059$ & \\
\hline \multicolumn{5}{|l|}{ Leptin (ng/ml) } \\
\hline$M$ & $3.10 \pm 0.17$ & $9.91 \pm 0.38$ & $17.6 \pm 0.86$ & 0.0001 \\
\hline$F$ & $12.2 \pm 0.4$ & $22.84 \pm 0.97$ & $44.6 \pm 1.85$ & \\
\hline$T$ & $9.42 \pm 0.48$ & $17.51 \pm 0.97$ & $36.13 \pm 1.67$ & \\
\hline \multicolumn{5}{|l|}{ Fasting Insulin (pmol/L) } \\
\hline M & $62.6 \pm 4.23$ & $67.07 \pm 5.27$ & $111.9 \pm 5.6$ & 0.0001 \\
\hline $\mathrm{F}$ & $54.85 \pm 2.33$ & $75.84 \pm 6.26$ & $103.3 \pm 3.64$ & \\
\hline$T$ & $57.205 \pm 2.089$ & $72.23 \pm 4.28$ & $106.03 \pm 3.066$ & \\
\hline \multicolumn{5}{|l|}{ Fasting Glucose $(\mathrm{mmol} / \mathrm{L})$} \\
\hline$M$ & $4.84 \pm 0.07$ & $5.16 \pm 0.05$ & $5.06 \pm 0.09$ & 0.0001 \\
\hline $\mathrm{F}$ & $4.65 \pm 0.05$ & $4.97 \pm 0.08$ & $5.06 \pm 0.06$ & \\
\hline $\mathrm{T}$ & $4.71 \pm 0.041$ & $5.051 \pm 0.057$ & $5.06 \pm 0.05$ & \\
\hline
\end{tabular}


subjects compared with normal weight controls ( $\mathrm{p}<$ 0.0001 ). The biochemical parameters in the three groups of males and females are presented in Table 2. All parameters were significantly elevated in the overweight and obese subjects, except HDL-cholesterol, which was significantly lower compared to the normal weight group.

The genotype and allele frequency of the Gln27Glu polymorphism was calculated in the male and females and the results are presented in Table 3 . The overweight and obese subjects were separated from the normal weight group and the Gln27Glu genotype and allele frequency was calculated separately in each group. The allelic frequency was not elevated significantly in the overweight and obese female and male groups. However, the Glu27 homozygote had significant greater BMI, waist and hip circumference and significant higher concentration of triglyceride, leptin and insulin compared to the Gln27 homozygote (Table 4).

The main findings of the present study show that the male and female overweight and obese subjects do not differ in the genotype and allele frequencies of Glu27, however, the subjects who are Glu27 homozygote have greater BMI, waist and hip circumference, but not waist-to-hip ratios (abdominal obesity). These are associated with higher levels of triglyceride, serum leptin and insulin levels. There were no difference in the alleles frequency amongst overweight, obese and the control lean groups. These observations demonstrate that the Glu27 genotype of the $\beta 2 A R$ gene is related to some obesity phenotypes and higher triglyceride, insulin and leptin levels. Our results are in agreement with those of many investigators who reported that the Glu27Gln genotype of the $\beta 2 A R$ gene has a well established association with obesity [14]. Subjects who are Glu27 homozygotes have excess body fat and increased fat cell size compared with Gln homozygotes in a white population and also suffers from abdominal obesity and insulin resistance [15]. Similarly in another study Kunnas et al., observed significantly higher amount of visceral fat in women with Glu allele compare to Gln/Gln homozygote [17]. Masuo et al., have reported that the mutations in the $\beta 2 A R$ gene are associated with increased insulin resistance, adiposity, and blood pressure accompanied by higher plasma norepinephrine and

Table 3 Distribution of the genotypes, alleles frequencies and odd ratio of the $\beta 2$ Gln27Glu polymorphism in overweight and control subjects

\begin{tabular}{|c|c|c|c|c|c|c|}
\hline Genotype & Sex & $\begin{array}{c}\text { Control } \\
M: 35 \\
F: 80 \\
T= \\
115\end{array}$ & $\begin{array}{l}\text { Overweight } \\
\text { M:28 } \\
\text { F: } 40 \\
T=68\end{array}$ & $\begin{array}{l}\text { Obese } \\
\text { M:46 } \\
\text { F: } 100 T= \\
146\end{array}$ & $\begin{array}{l}\chi^{2} \\
\text { Odds ratio(95\% Cl) }\end{array}$ & $P$-value \\
\hline \multicolumn{7}{|c|}{ Genotype Frequency } \\
\hline \multirow[t]{3}{*}{ GIn\GIn } & M & $\begin{array}{c}24 \\
(68.57)\end{array}$ & $17(60.7)$ & $27(58.67)$ & $\begin{array}{l}\chi^{2} \\
M=1.19 \\
F=2.23\end{array}$ & $\begin{array}{l}P \text { value } \\
M=0.880\end{array}$ \\
\hline & $\bar{F}$ & $\begin{array}{c}51 \\
(63.75)\end{array}$ & $26(65)$ & $60(60)$ & & \\
\hline & $\mathrm{T}$ & $75(65.2)$ & $43(63.2)$ & $87(59.6)$ & & \\
\hline \multirow[t]{3}{*}{ Gln\Glu } & $M$ & $\begin{array}{c}5 \\
(14.28)\end{array}$ & $5(17.58)$ & $7(15.21)$ & $\begin{array}{l}\text { Odds ratio }(95 \% \text { Cl) Control vs } \\
\text { OW } \\
1.1(0.5,2.39)\end{array}$ & $F=0.693$ \\
\hline & $\mathrm{F}$ & $\begin{array}{c}13 \\
(16.25) \\
\end{array}$ & $6(15)$ & $12(12)$ & & \\
\hline & $\mathrm{T}$ & $18(15.7)$ & $11(16.2)$ & 19(13.0) & & \\
\hline \multirow[t]{3}{*}{ Glu\Glu } & $M$ & $\begin{array}{c}6 \\
(17.12)\end{array}$ & $6(21.42)$ & $12(26)$ & $\begin{array}{l}\text { Odds ratio }(95 \% \mathrm{Cl}) \text { Control vs } \\
\text { Obese } \\
1.567(0.85,2.87)\end{array}$ & $\begin{array}{l}P \text { value for Odds ratio in normal vs overweight and } \\
\text { normal vs obese: } \\
P>0.05\end{array}$ \\
\hline & $\bar{F}$ & $16(20)$ & $8(20)$ & $28(28)$ & & \\
\hline & $\mathrm{T}$ & $22(19.1)$ & 14(20.6) & $40(27.4)$ & & \\
\hline \multicolumn{7}{|c|}{ Allele Frequency } \\
\hline $\begin{array}{l}\text { Allele } \\
\text { Gln27 }\end{array}$ & $T$ & $73.0 \%$ & $71.3 \%$ & $66.1 \%$ & $\begin{array}{l}\text { Odds ratio }(95 \% \text { Cl) Control vs } \\
\text { OW } \\
0.95(0.71,1.27)\end{array}$ & $P=0.70$ \\
\hline $\begin{array}{l}\text { Allele } \\
\text { Glu27 }\end{array}$ & $\mathrm{T}$ & $27.0 \%$ & $28.7 \%$ & $33.9 \%$ & $\begin{array}{l}\text { Odds ratio }(95 \% \mathrm{Cl}) \text { Control vs } \\
\text { Obese } \\
0.87(0.74,1.2)\end{array}$ & $P=0.09$ \\
\hline
\end{tabular}


Table 4 Phenotypic Characteristics of the Subjects According to $32 A R$ Polymorphism at Codon 27

\begin{tabular}{|c|c|c|c|c|}
\hline Variables & $\begin{array}{c}\mathrm{Gln} \backslash \mathrm{Gln} \\
(\mathrm{n}=205) \\
\text { mean } \pm S E\end{array}$ & $\begin{array}{c}\text { Gln\Glu } \\
(n=48) \\
\text { mean } \pm S E\end{array}$ & $\begin{array}{c}\text { Glu\Glu } \\
(n=76) \\
\text { mean } \pm S E\end{array}$ & $\begin{array}{c}P \text { - } \\
\text { value }\end{array}$ \\
\hline BMI $\left(\mathrm{kg} / \mathrm{m}^{2}\right)$ & $\begin{array}{c}27.917 \pm \\
.508\end{array}$ & $27.880 \pm .96$ & $\begin{array}{c}30.483 \pm \\
.908\end{array}$ & 0.03 \\
\hline$\overline{\text { Waist(cm) }}$ & $\begin{array}{l}86.51 \pm \\
1.213\end{array}$ & $\begin{array}{l}88.10 \pm \\
2.799\end{array}$ & $\begin{array}{l}93.59 \pm \\
2.390\end{array}$ & 0.02 \\
\hline $\mathrm{Hip}(\mathrm{cm})$ & $\begin{array}{l}106.15 \pm \\
1.016\end{array}$ & $\begin{array}{c}108.38 \pm \\
2.350\end{array}$ & $\begin{array}{c}112.07 \pm \\
1.767\end{array}$ & 0.014 \\
\hline $\mathrm{W} / \mathrm{H}$ ratio & $.8112 \pm .006$ & $.8098 \pm .014$ & $.8300 \pm .011$ & 0.3 \\
\hline Cholesterol (mmol/L) & $3.996 \pm .06$ & $3.944 \pm 104$ & $4.117 \pm .105$ & 0.48 \\
\hline Triglyceride $(\mathrm{mmol} / \mathrm{L})$ & $.980 \pm .030$ & $1.088 \pm .064$ & $1.260 \pm .057$ & 0.0001 \\
\hline $\begin{array}{l}\text { HDL-cholesterol } \\
(\mathrm{mmol} / \mathrm{L})\end{array}$ & $\begin{array}{l}1.2093 \pm \\
.0235\end{array}$ & $\begin{array}{l}1.1683 \pm \\
.0525 \\
\end{array}$ & $\begin{array}{l}1.1204 \pm \\
.0375 \\
\end{array}$ & 0.142 \\
\hline $\begin{array}{l}\text { LDL-cholesterol } \\
(\mathrm{mmol} / \mathrm{L})\end{array}$ & $\begin{array}{c}2.074 \pm \\
.0562 \\
\end{array}$ & $2.11 \pm .11$ & $2.179 \pm .09$ & 0.62 \\
\hline Leptin (ng/ml) & $\begin{array}{c}21.39 \pm \\
1.190\end{array}$ & $21.99 \pm 2.62$ & $\begin{array}{c}27.74 \pm \\
2.549\end{array}$ & 0.04 \\
\hline $\begin{array}{l}\text { Fasting Insulin } \\
\text { (pmol/L) }\end{array}$ & $\begin{array}{l}78.525 \pm \\
2.758\end{array}$ & $\begin{array}{c}79.779 \pm \\
4.677\end{array}$ & $\begin{array}{c}92.683 \pm \\
4.632\end{array}$ & 0.02 \\
\hline $\begin{array}{l}\text { Fasting Glucose } \\
(\mathrm{mmol} / \mathrm{L})\end{array}$ & $4.911 \pm .038$ & $5.000 \pm 095$ & $\begin{array}{l}4.961 \pm \\
.0438\end{array}$ & 0.53 \\
\hline
\end{tabular}

NOTE: Values are mean \pm SEM. Abbreviations: BMI, body mass index; W/H, waist hip ratio.

leptin levels[16]. Ishiyama et al., have suggested an association of polymorphisms in the $\beta 2 \mathrm{AR}$ receptor gene with obesity, hypertriglyceridemia, and diabetes mellitus in Japanese subjects [18]. They observed that the Gln27Glu heterozygotes were twice as common in obese subjects, and that the frequency of the Glu27 allele was also higher in patients with type 2 diabetes mellitus than in nondiabetic subjects [18]. Another Japanese study reported that the Gln27Glu $\beta 2 \mathrm{AR}$ receptor variant was associated with obesity in males [19]. Ukkola et al., found that gene-to-gene interactions among the $\alpha_{2^{-}}, \beta_{2^{-}}$ , and $\beta$-adrenergic receptor genes contributed to the phenotypic variability in abdominal obesity and plasma lipid and lipoprotein in a family study in Québec [20]. Though, these and other studies show an association between the Gln27Glu, however, there is considerable debate on this association, because there have been several studies that have failed to show the significant association between $\beta 2 \mathrm{AR}$ gene polymorphism and obesity [11-13]. Hayakawa et al., reported that Gln27Glu and Arg16Gly polymorphisms of the $\beta 2 \mathrm{AR}$ gene are not a major contributing factor to obesity, blood pressure, serum lipid levels, uric acid, or free fatty acid levels in 210 Japanese men [11]. Oberkofler et al., reported that Gln27Glu polymorphisms in the $\beta 2 \mathrm{AR}$ gene is not a major factor contributing to morbid obesity in Austrian women [13]. Kim et al., found that the Glu27Glu and Arg16Gly polymorphisms of the $\beta 2 A R$ gene are not major factor contributing towards obesity in Korean subjects [21].

Furthermore, a few studies report gender-specific association between $\beta 2 \mathrm{AR}$ polymorphism and obesity. Hellstrom et al., suggested that a positive association between obesity and the Glu27 genetic variant in $\beta 2 \mathrm{AR}$ exists in females, whereas there is a negative correlation between Glu27 and obesity in Swedish male subjects [15]. Although the reasons for this discrepancy among studies are unclear, they may be due to the difference in the degree of obesity among study subjects or may be due to genetic variations between ethnic groups. However, further studies in larger populations are required to verify these results.

Our findings provide strong evidence on the influence of the Gln27Glu genetic variants on lipid phenotypes, insulin and leptin levels in overweight/obese Saudi subjects.

\section{Acknowledgements}

This study was supported by a grant (numbers D/1/27) from the Research Centre for Female Scientific and Medical Colleges, King Saud University, Saudi Arabia. We thank all the subjects for their cooperation and participation in the study. We would also like to thank all the participants (researchers, technicians and nurses) for their notable contribution.

\section{Author details}

${ }^{1}$ Department of Zoology, Center for Scientific and Medical Female Colleges, King Saud University, P.O. Box 22455, Riyadh, Saudi Arabia. ${ }^{2}$ Department of Biochemistry, Center for Scientific and Medical Female Colleges, King Saud University, P.O. Box 22452, Riyadh, Saudi Arabia. ${ }^{3}$ Department of Obstetrics \& Gynecology, Umm-Al-Qura University, P.O.Box 424, 21955, Makkah, Saudi Arabia. ${ }^{4}$ Department of Genetics, King Faisal Specialist Hospital and Research Center P.O. Box 3354, Riyadh 11211, Saudi Arabia. ${ }^{5}$ Biostatistics, Epidemiology \& Scientific Computing (MBC - 03), King Faisal Specialist Hospital and Research Center, P. O. Box 3354, Riyadh 11211, Saudi Arabia.

\section{Authors' contributions}

MHD designed the experiment, analyzed the data and wrote the manuscript. AW helped in writing the draft of the manuscript and in statistical analysis. ANO consultation and result interpretation. MHD arranged the subjects/samples of the study. NAA helped in result interpretation. AE performed all the statistical analysis and SZ performed biochemical analysis. All authors read and approved the final manuscript.

\section{Competing interests}

The authors declare that they have no competing interests.

Received: 11 July 2010 Accepted: 25 August 2010

Published: 25 August 2010

\section{References}

1. Bouchard C: Current understanding of the etiology of obesity: Genetic and non-genetic factors. Am J Clin Nutr 1991, 53:1561-1565.

2. Wei-Tsung Kao, Yen Chieh Yung, Lung Wey For: The effects of beta 2 adrenergic receptor gene polymorphism in lipid profiles. Lipids in Health and Diseases 2009, 50:1-8.

3. Berlan M: Fat cell adrenergic receptor and the control of white and brown fat cell function. J Lipid Res 1993, 34:1057-1091.

4. Lonnqvist F, Wahrenberg H, Hellstorm L, Reynisdottir S, Arner P: Lipolytic catecholamine resistance due to decreased beta 2-adrenoceptor expression in fat cells. J Clin Invest 1992, 90(6):2175-2186.

5. Encksson S, Shimizu M, Lonnovist F, Nordenstorm J, Arner P: Demonstration and of an in vivo functional $\beta_{3}$-adrenoceptor in man. J Clin Invest 1995, 95:2239-2245. 
6. Liggett SB: Pharmacogenetics of $\beta$ 1- and $\beta$ 2-adrenergic receptors. Pharmacology 2000, 61(3):167-173.

7. Green SA, Turki J, Innis M, Liggett SB: Amino-terminal polymorphisms of the human $\beta 2$-adrenergic receptor impart distinct agonist-promoted regulator properties. Biochemistry 1994, 33:9414-9419.

8. Ishiyama-Shigemoto S, Yamada K, Yuan X, Ichikawa F, Nonaka K: Association of polymorphisms in the $\beta 2$-adrenergic receptor gene with obesity, hypertriglyceridaemia, and diabetes mellitus. Diabetologia 1999, 42:98-101.

9. Iwamoto N, Ogawa Y, Kajihara S, Hisatomi A, Yasutake T, Yoshimura T, Mizuta T, Hara T, Ozaki I, Yamamoto K: Gln27Glu $\beta$ 2-adrenergic receptor variant is associated with hypertriglyceridemia and the development of fatty liver. Clin Chim Acta 2001, 314:85-91.

10. Arner P: Genetic variance and lipolysis regulation: implications for obesity. Ann Med 2001, 33:542-546.

11. Hayakawa T, Nagai Y, Kahara T, Yamashita H, Takamura T, Abe T, Nomura G, Kobayashi K: Gln27Glu and Arg16Gly polymorphisms of the beta2adrenergic receptor gene are not associated with obesity in Japanese men. Metabolism 2000, 49:1215-1218.

12. Kortner B, Wolf AM, Wendt D, Beisiegel U, Evans D: Lack of association between a human beta2-adrenoceptor gene polymorphism (gln27glu) and morbid obesity. Int I Obes Relat Metab Disord 2000, 23:1099-1100.

13. Oberkofler H, Esterbauer H, Hell E: The Gln27Glu polymorphismin the beta2-adrenergic receptor gene is not associated with morbid obesity in Austrian women. Int J Obes Relat Metab Disord 2000, 24:388-390.

14. Large V, Hellstrom L, Reynisdottir S, Lonnqvist F, Eriksson P, Lannfelt L, Arner P: Human beta-2 adrenoceptor gene polymorphisms are highly frequent in obesity and associate with altered adipocyte beta- 2 adrenoceptor function. J Clin Invest 1997, 100:3005-3012.

15. Hellstrom $L$, Large $V$, Reynisdottir $S$, Wahrenberg $H$, Arner P: The different effects of Gln27Glu $\beta_{2}$-adrenoceptor gene polymorphism on obesity in males and in females. J Intern Med 1999, 245:253-259.

16. Masuo K, Katsuya T, Kawaguchi H, Fu Y, Rakugi H, Ogihara T, Tuck ML: $\beta_{2^{-}}$ adrenoceptor polymorphisms relate to obesity through blunted leptin mediated sympathetic activation. Am J Hypertens 2006, 19:1084-1091.

17. Kunnas T, Lachitioo R, Kortelainen M-J, Kalela A, Nikkari ST: Gln27Glu variant of Beta 2-adrenoreceptor gene affects male type fat accumulation in women. Lipids in Health and Disease 2009, 43:1-4.

18. Ishiyama-Shigemoto S, Yamada K, Yuan X, Nonaka K: Association of polymorphism in the $\beta 2$-adrenergic receptor gene with obesity, hypertriglyceridemia, and diabetes mellitus. Diabetologia 1999, 42:98-101.

19. Mori Y, Kim-Motoyama H, Ito Y, Katakura T, Yasuda Kazuki, IshiyamaShigemoto Satomi, Yamada Kentaro, Akanuma Yasuo, Ohashi Yasuo, Kimura Satoshi, Yazaki Yoshio, Kadowaki Takashi: The Gln27Glu ß2adrenergic receptor variant is associated with obesity due to subcutaneous fat accumulation in Japanese men. Biochem Biophys Res Commun 1999, 258:138-140.

20. Ukkola O, Rankinen $\mathrm{O}$, Weisnage SJ: Interaction among the $\alpha 2-, \beta 2-$, and $\beta 3$-adrenergic receptor genes and obesity-related phenotypes in the Quebec family study. Metabolism 2000, 49:1063-1070.

21. Kim S, Kim D, Seo IA, Lee M, Kim K, Lee M: Significance of beta2adrenergic receptor gene polymorphism in obesity and type 2 diabetes mellitus in Korean subjects. Metabolism 2002, 51:833-37.

doi:10.1186/1476-511X-9-90

Cite this article as: Daghestani et al:: The Gln27Glu Polymorphism in $\beta 2-$ Adrenergic receptor gene is linked to hypertriglyceridemia,

hyperinsulinemia and hyperleptinemia in Saudis. Lipids in Health and Disease 2010 9:90.

\section{Submit your next manuscript to BioMed Central and take full advantage of:}

- Convenient online submission

- Thorough peer review

- No space constraints or color figure charges

- Immediate publication on acceptance

- Inclusion in PubMed, CAS, Scopus and Google Scholar

- Research which is freely available for redistribution

Submit your manuscript at www.biomedcentral.com/submit
Biomed Central 